\title{
Understanding mechanisms for the end-Permian mass extinction and the protracted Early Triassic aftermath and recovery
}

\begin{abstract}
David J. Bottjer*, Dept. of Earth Sciences, University of Southern California, Los Angeles, California 90089-0740, USA; Matthew E. Clapham*, Dept. of Earth and Planetary Sciences, University of California, 1156 High St., Santa Cruz, California 95064, USA; Margaret L. Fraiser*, Dept. of Geosciences, University of Wisconsin, Milwaukee, Wisconsin 53203, USA; and Catherine M. Powers*, Dept. of Earth Sciences, University of Southern California, Los Angeles, California 90089-0740, USA
\end{abstract}

\begin{abstract}
Modern study of the end-Permian mass extinction in the marine realm has involved intensive documentation of the fossil content, sedimentology, and chemostratigraphy of individual stratigraphic sections where the mass extinction interval is well preserved. These studies, coupled with innovative modeling of environmental conditions, have produced specific hypotheses for the mechanisms that caused the mass extinction and associated environmental stress. New paleobiological studies on the environmental distribution and ecological importance of brachiopods, benthic molluscs, and bryozoans support the hypothesis that stressful ocean conditions-primarily elevated $\mathrm{H}_{2} \mathrm{~S}$ levels (euxinia) but also heightened $\mathrm{CO}_{2}$ concentrations-were the prime causes of the end-Permian mass extinction. These studies also further demonstrate that both the Late Permian interval preceding this mass extinction and the Early Triassic interval that followed were times of similar elevated environmental stress. In the low-diversity Early Triassic biosphere, huge numbers of benthic molluscs, in particular four cosmopolitan genera of bivalves, typically covered the seafloor. That a few marine genera thrived during this time indicates a greater than usual tolerance to some combination of marine anoxia, as well as elevated $\mathrm{CO}_{2}$ and/or increased $\mathrm{H}_{2} \mathrm{~S}$ concentrations. Research focusing on experiments with modern organisms similar to those that died, as well as those that thrived, in microcosms where levels of $\mathrm{O}_{2}, \mathrm{CO}_{2}$, and $\mathrm{H}_{2} \mathrm{~S}$ can be experimentally manipulated will enable an even more detailed understanding of the nature of this greatest Phanerozoic biotic crisis.
\end{abstract}

\section{INTRODUCTION}

A major drop in global biodiversity defines mass extinctions, as revealed by compilations of taxonomic richness (Sepkoski, 1981). The end-Permian mass extinction (ca. $252 \mathrm{Ma}$ ) has long been recognized as the most severe biodiversity crisis in the Phanerozoic (Erwin, 2006), and its associated faunal shift from the brachiopod-rich Paleozoic Fauna to the mollusc-rich Modern Fauna (Gould and Calloway, 1980; Sepkoski, 1981) represents a fundamental change in the taxonomic structure as well as the ecological architecture of marine animal ecosystems. A range of mechanisms from oceanographic to climatic to extraterrestrial has been proposed to explain the end-Permian mass extinction (e.g., Renne et al., 1995; Knoll et al., 1996; Wignall and Twitchett, 1996; Isozaki, 1997; Krull and Retallack, 2000; Becker et al., 2001; Grice et al., 2005). Similarly, a variety of evidence shows that environmental stress lingered through the Early Triassic, strongly affecting recovery processes (e.g., Schubert and Bottjer, 1992; Woods et al., 1999; Payne et al., 2004; Pruss et al., 2006).

We focus here on paleobiological approaches that incorporate ecological, environmental, and biogeographic analyses during the time leading up to the end-Permian mass extinction as well as the subsequent Early Triassic aftermath and recovery to test the variety of mechanisms hypothesized for this interval of biotic crisis. These new analyses provide the foundation for future experiments in which environmental conditions can be manipulated in microcosms, thus allowing a more comprehensive understanding of the largest biotic crisis of the Phanerozoic.

\section{ANALYTICAL APPROACHES}

Recent paleobiological studies have adopted a more quantitative approach to document hierarchical changes, from local to global scales, in the marine biosphere during the Late Permian extinctions and the Early Triassic recovery. The combination of paleoecological analysis, based on counts of fossil assemblages and shell accumulations, with assessment of the changing habitat preferences and geographic distribution of environmentally sensitive animal groups provides a clearer picture of the ecological processes operating at a variety of scales during the Permo-Triassic extinction and recovery interval. These paleoecological analyses build upon results from modern ecology, indicating that (1) abundant species typically play a crucial role in controlling the ecological functioning of their communities (Power et al., 1996), and (2) the correspondence between a taxon's abundance in marine life and death assemblages is relatively faithful (Kidwell, 2001, 2002). As such, fossil accumulations, known as shell beds, provide a rich source of paleoecological data. Shell beds have been used to estimate the identity of ecologically dominant groups in the fossil record (e.g., Clapham et al., 2006) and as proxies for numerical dominance of skeletonized benthic marine invertebrates during important biological transitions, such as the Ordovician Radiation (e.g., Li and Droser, 1999). Both quantitative accounts of

*E-mails: dbottjer@usc.edu, mclapham@ucsc.edu, mfraiser@uwm.edu, jamet@usc.edu

GSA Today, v. 18, no. 9, doi: 10.1130/GSATG8A.1 

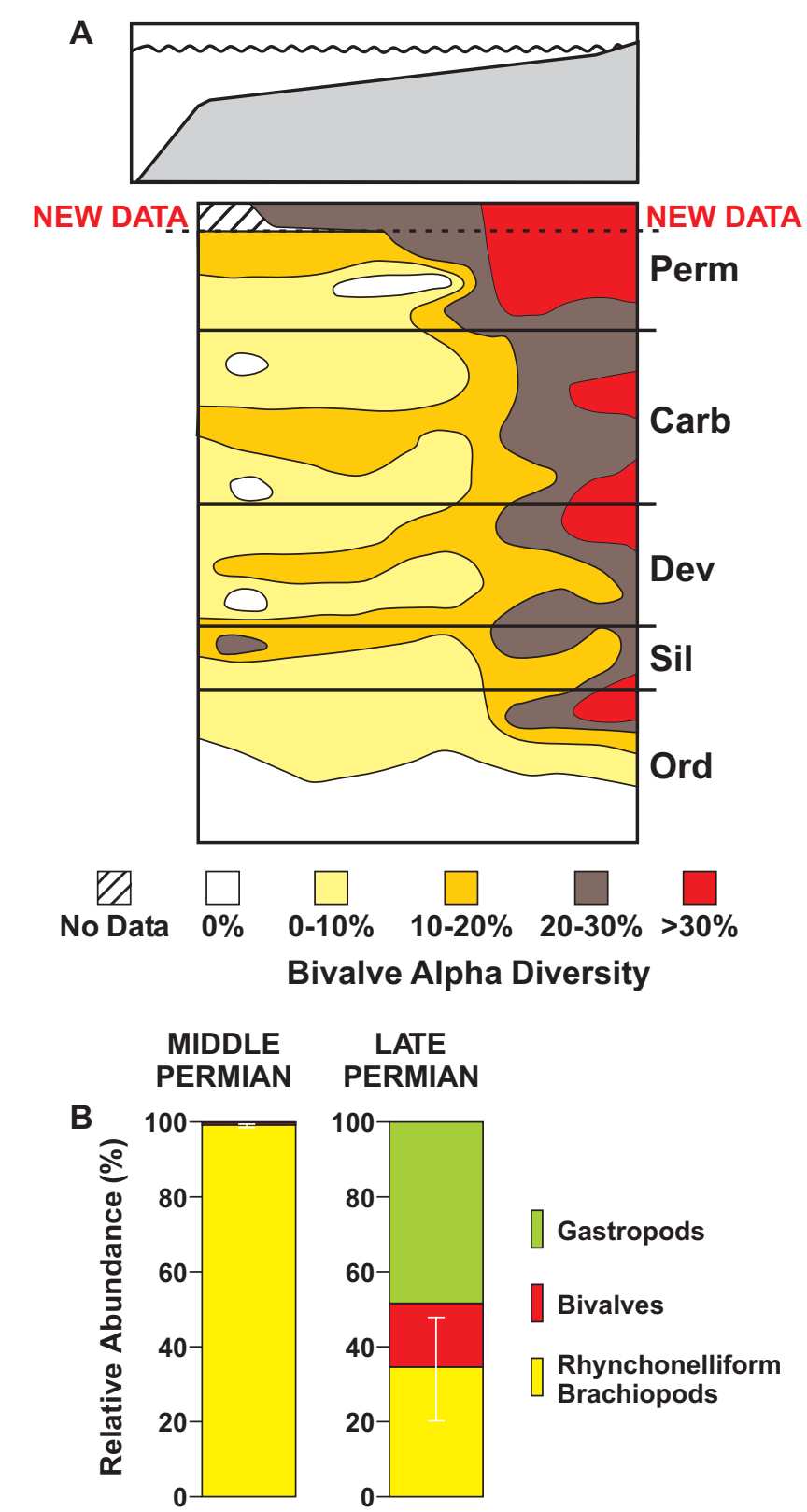

Figure 1. Paleoecological changes in brachiopods and molluscs in the Paleozoic. (A) Time-environment pattern of Paleozoic bivalve alpha diversity, indicating an initial offshore expansion of diverse bivalve assemblages in the Permian; modified from Miller (1988). New Late Permian data (from Clapham and Bottjer, 2007a) show a major offshore increase in bivalve diversity. Hatched pattern in Late Permian slope and basin environments indicates a lack of data. (B) Mean relative abundance of rhynchonelliform brachiopods, bivalves, and gastropods from new Middle and Late Permian offshore samples (from Clapham and Bottjer, 2007a). Error bars indicate 95\% confidence intervals.

fossil abundance (Clapham and Bottjer, 2007a, 2007b; Fraiser and Bottjer, 2007b) and semiquantitative assessment of the dominant group in shell accumulations (Fraiser and Bottjer, 2007 b) document profound ecological changes in marine animal communities during the Late Permian and Early Triassic.

As part of the ecological assessment of organisms before and after mass extinctions, the paleoenvironmental context of important taxa must also be considered in order to under- stand how changes in environmental conditions affect different habitats. Assessment of shifts in habitat occupation and environmental variation in diversity also provides a broader perspective on local community changes reconstructed from quantitative counts.

Time-environment ( $T-E)$ diagrams, which plot the presence or absence, diversity, or abundance of particular taxa against marine environments and geological time, have long been used to understand the evolutionary paleoecology and distribution of these taxa through time (e.g., Jablonski et al., 1983; Sepkoski and Miller, 1985; Bottjer and Jablonski, 1988; Miller, 1988; Powers and Bottjer, 2007) (Figs. 1A and 2A) (for detailed methodology, see Powers and Bottjer, 2007). Once hierarchical biotic changes are addressed at the local community scale through quantitative paleoecological analysis and at the regional scale through documentation of habitat occupation with $T-E$ diagrams, the broadest scale of extinction processes is revealed by the changing paleobiogeographic patterns of specific animal groups (e.g., Powers and Pachut, 2008). Plots on paleogeographic maps of occurrences gathered from the primary literature document geographic variations in the severity of the extinction, including the existence of refugia where animals were able to avoid the most severe environmental perturbations and survive to recolonize the globe after conditions became more favorable.

\section{PROPOSED MECHANISMS FOR LONG-TERM ENVIRONMENTAL STRESS AND MASS EXTINCTION}

Mechanisms for environmental stress during the PermianTriassic transition, including the end-Permian mass extinction, varied over space and time. Potential sources of environmental stress include a range of gradual and catastrophic processes, such as reduced concentrations of atmospheric $\mathrm{O}_{2}$ (Huey and Ward, 2005), widespread oceanic anoxia (Wignall and Twitchett, 1996; Isozaki, 1997; Huey and Ward, 2005), euxinia $\left(\mathrm{H}_{2} \mathrm{~S}\right.$ poisoning) (Nielsen and Shen, 2004; Grice et al., 2005; Kump et al., 2005), increased oceanic $\mathrm{CO}_{2}$ concentrations (hypercapnia) (Knoll et al., 1996), massive volcanism and global warming (Renne et al., 1995; Kamo et al., 2003), $\mathrm{CH}_{4}$ oxidation (Krull and Retallack, 2000; Ryskin, 2003), and an extraterrestrial impact (Becker et al., 2001).

Environmental stress during the Late Permian was likely initiated at the end of the Middle Permian, during the development of deep-water anoxic conditions associated with the PermianTriassic superanoxia event (Isozaki, 1997). Deep waters were even euxinic in some basins during the early Late Permian, several million years before the end-Permian mass extinction (Nielsen and Shen, 2004). Geochemical and sedimentological data indicate that Late Permian deep-water environmental stress, including euxinia and high $\mathrm{CO}_{2}$ concentrations, persisted into the Early Triassic (Isozaki, 1997; Woods et al., 1999; Payne et al., 2004; Pruss et al., 2004) and that upward excursion of these deep-water conditions into shallow environments was the ultimate cause of the end-Permian mass extinction, during which $80 \%$ of marine species and $49 \%$ and $63 \%$ of marine and terrestrial families disappeared (Raup and Sepkoski, 1982; Stanley and Yang, 1994; Benton, 1995). These deepwater, and intermittently shallow-water, $\mathrm{H}_{2} \mathrm{~S}$-rich conditions were exacerbated by the effects of massive Siberian Trap 
A

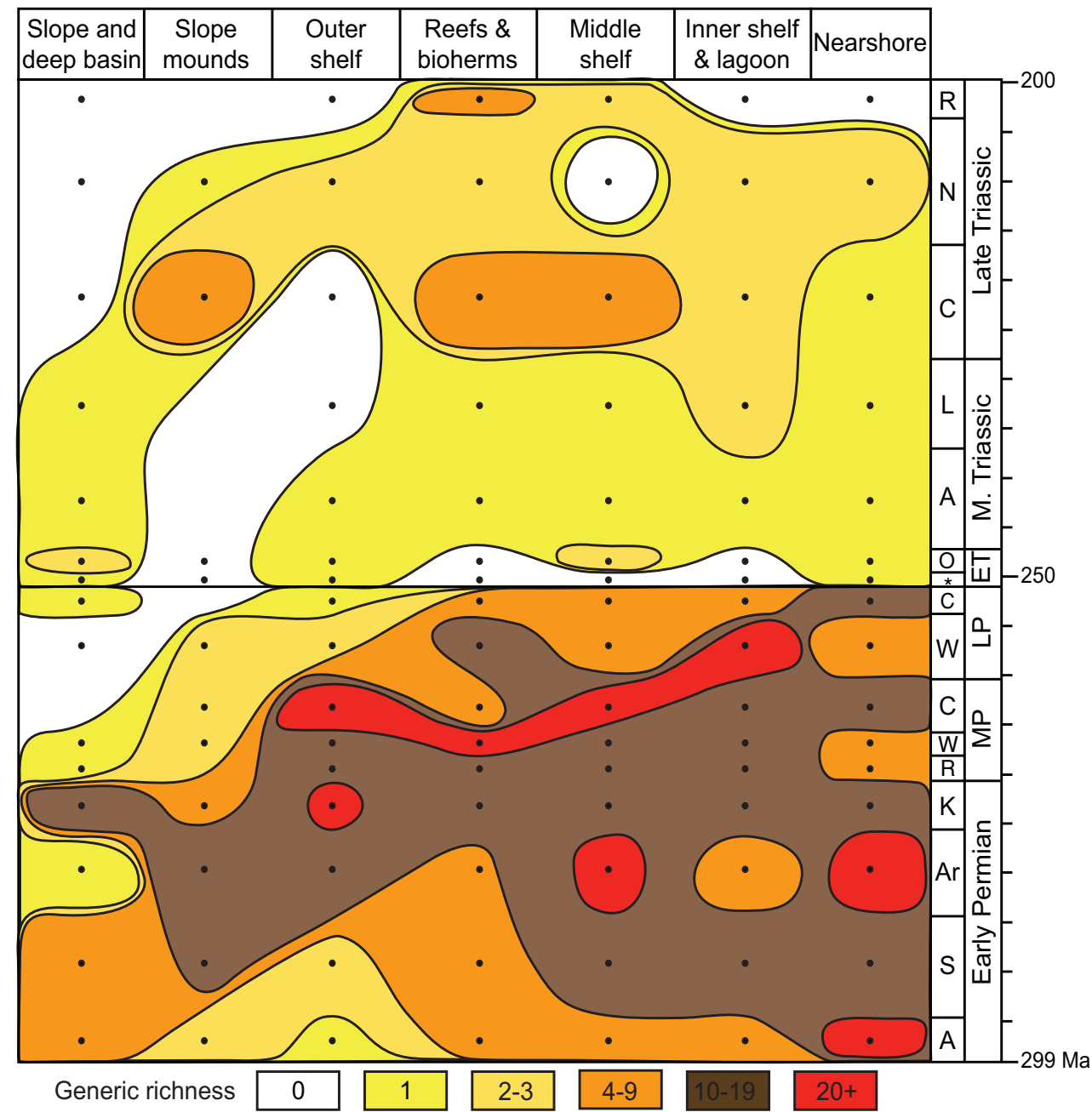

B

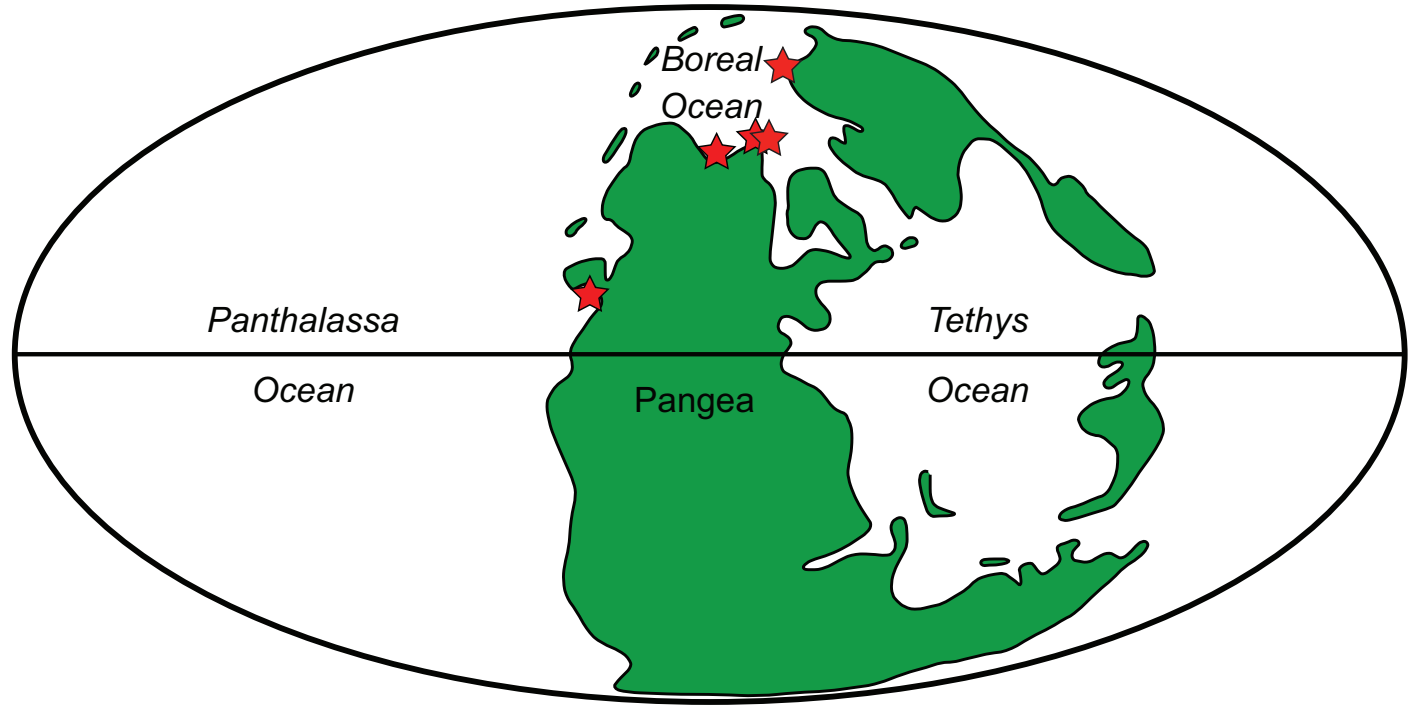

Figure 2. Environmental and geographic distribution of stenolaemate bryozoans. (A) Contoured Permian-Triassic time-environment (T-E) diagram of marine bryozoans. Each dot represents a data point, either for assemblage with the greatest bryozoan generic richness in each $T-E$ bin, or for absence of bryozoans validated by the taphonomic control group; modified from Powers and Bottjer (2007). Abbreviations from the bottom up: A-Asselian; S-Sakmarian; Ar-Artinskian; K-Kungurian; R-Roadian; W-Wordian; C—Capitanian; W-Wuchiapingian; C—Changhsingian; *_Induan; O_Olenekian; A-Anisian; L-Ladinian; C-Carnian; N-Norian; R-Rhaetian; MP_Middle Permian; LP-Late Permian; ET-Early Triassic. (B) Paleobiogeographic distribution of Early Triassic bryozoans indicated by stars. Modified from Powers and Pachut (2008). 
volcanism (Renne et al., 1995; Kamo et al., 2003), which increased atmospheric $\mathrm{CO}_{2}$ concentrations, enhancing the possibility for hypercapnia and/or ocean acidification and biocalcification crises (Knoll et al., 1996).

\section{PERMIAN PRELUDE}

Compilations of marine animal diversity show that the shift in global taxonomic richness from diverse rhynchonelliform ("articulate") brachiopods to diverse molluscs occurred at the Permian-Triassic boundary, coincident with the end-Permian mass extinction event (e.g., Sepkoski, 1981). That concurrence has been used to argue that the mass extinction was the primary cause of this ecological change by eliminating previously dominant brachiopods and allowing molluscs to rise to prominence (e.g., Gould and Calloway, 1980). Pioneering environmental and ecological analysis of the prelude to this transition through the use of T-E diagrams (e.g., Miller, 1988) showed the beginnings of an increase in bivalve molluscs across middle shelf environments in the Middle Permian (Fig. 1A), although data were not available from the Late Permian (Clapham and Bottjer, 2007a, 2007b) until recently.

Ecological changes at the local paleocommunity level prior to the end-Permian extinction have been reconstructed from abundance counts of $>33,000$ fossil individuals from 24 silicified Middle and Late Permian paleocommunities (Clapham and Bottjer, 2007a, 2007b). The counts document a significant ecological shift in fossil abundance in offshore environments, from rhynchonelliform brachiopods to gastropods and bivalves, between the Middle and Late Permian, despite the fact that the relative global taxonomic richness of those groups was essentially unchanged (Fig. 1B). The shift in numerical dominance was also accompanied by major ecological changes as motile gastropods and infaunal bivalves became more prominent members of Late Permian communities.

A compilation of the global onshore-offshore distribution of marine bryozoans within nearly 400 Permian-Triassic assemblages reveals that the pronounced ecological changes in local paleocommunities were symptomatic of a more widespread phenomenon affecting offshore habitats in the Late Permian. The generic richness of bryozoans declined significantly in the Late Permian, with the most severe effects observed in offshore settings from which bryozoans were progressively restricted and finally eliminated significantly before the extinction event (Powers and Bottjer, 2007) (Fig. 2A). Although not based on a similar comprehensive global data set, onshore-offshore trends in the mean abundance of microgastropods and maximum gastropod size can be observed in the Late Permian, with larger gastropods inhabiting shallow settings, while the microgastropod abundance and maximum size in offshore habitats were strikingly similar to the Early Triassic (Clapham and Bottjer, 2007a).

These new data on the environmental distribution and ecological structure of Late Permian assemblages further demonstrate that processes leading to the end-Permian mass extinction commenced around the Middle-Late Permian boundary (Clapham and Bottjer, 2007a, 2007b; Powers and Bottjer, 2007). The preferential drop in abundance of brachiopods and assemblage diversity of bryozoans in Late Permian offshore environments, coincident with the increase in molluscan abundance, indicates that stressful conditions for brachiopods and bryozoans were encroaching over time from the deep ocean onto shelf environments, and argues against an extraterrestrial cause for the extinction. That this ultimately led to the endPermian demise of brachiopods and bryozoans, contrasted with an increase in molluscs, indicates that the anoxic, and locally euxinic, nature of this deep ocean water was highly stressful to brachiopods and bryozoans but not to certain benthic molluscs (Clapham and Bottjer, 2007b).

\section{EARLY TRIASSIC AFTERMATH AND RECOVERY}

The end-Permian mass extinction marks the beginning of the second phase of the prolonged Permian-Triassic biotic crisis, with biotic recovery beginning only 4-5 m.y. later (Lehrmann et al., 2006), toward the end of the Early Triassic (Spathian). Full recovery, including a return to pre-extinction diversity and ecological complexity, did not occur until some time in the Middle Triassic (Hallam, 1991; Erwin and Pan, 1996). Carbon isotopic data demonstrate large negative and positive excursions throughout the Early Triassic, indicating changes in the carbon cycle not seen since Cambrian and earlier times (e.g., Atudorei, 1999; Payne et al., 2004; Corsetti et al., 2005; Pruss et al., 2006). Quantitative paleoecological analysis at various temporal and spatial scales has revealed short-term and long-term changes within benthic level-bottom shallow marine paleocommunities that were facilitated by protracted Early Triassic deleterious environmental conditions (Figs. 3 and 4).

One short-term paleoecological pattern revealed by analysis of Lower Triassic shell beds is the opportunistic proliferation of microgastropods-gastropods with greatest dimension $<1 \mathrm{~cm}$ - in shallow marine subtidal to middle shelf environments (Fraiser and Bottjer, 2004; Fraiser et al., 2005) (Fig. 4). Microgastropod-dominated shell beds occur globally during the aftermath of the end-Permian mass extinction and represent a non-actualistic phenomenon. Fraiser and Bottjer (2007a) proposed that microgastropods were able to survive the chemically and/or physiologically harsh environmental conditions during the Early Triassic better than most skeletonized benthic marine invertebrates. This phenomenon had begun by the Late Permian in offshore environments, supporting the hypothesis that poisonous deep-waters contributed to changes in paleocommunity structure (Clapham and Bottjer, 2007a).

Quantitative data of fossil marine assemblages found in The Paleobiology Database (www.paleodb.org) show that rhynchonelliform brachiopods, in contrast to benthic molluscs (bivalves and gastropods), declined in abundance throughout the Late Permian and Early Triassic before recovering to abundance levels similar to those of the Late Permian during the Middle and Late Triassic (Fig. 3) (Clapham and Bottjer, 2007b). Field examination of Lower Triassic shell beds from around the world reveals a similar trend: bivalves dominate $70 \%$ of Lower Triassic shell beds, and rhynchonelliform brachiopods dominate only a small percentage of the studied shell beds (Fig. 4). Four bivalve genera, Claraia, Eumorphotis, Promyalina, and Unionites, are the most widespread and numerically abundant bivalve genera during the Early Triassic (Hallam and Wignall, 1997; Fraiser and Bottjer, 2007b). Of these, Unionites is typically the most common in shallow marine environments. 


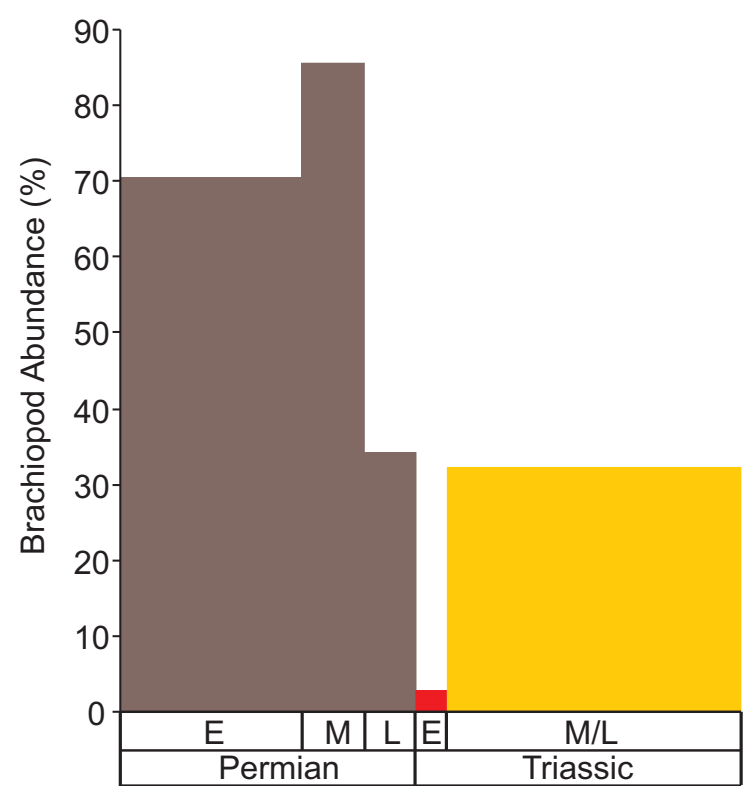

Figure 3. Relative abundance of rhynchonelliform brachiopods (normalized to include only brachiopods, bivalves, and gastropods) from 181 Permian and Triassic quantitative assemblages, indicating a Middle (M) to Late (L) Permian decline followed by a dramatic reduction in the Early (E) Triassic and then a recovery in the Middle and Late (M/L) Triassic. Modified from Clapham and Bottjer (2007b).

Analysis of shell bed data available in the primary literature places these results into a broader context (Fraiser and Bottjer, 2007b) (Figs. 4A and 4B). Tabulation of Ordovician to Permian and post-Early Triassic shell beds reflects major characteristics of Sepkoski's evolutionary faunas, with dominance by rhynchonelliform brachiopod shell beds during the Paleozoic (Fig. 4A) and dominance by bivalve shell beds during the post-Lower Triassic (Fig. 4B) (Fraiser and Bottjer, 2007b). Not only was there a short-term increase in bivalves during the Early Triassic, but a long-term, permanent change was also facilitated: It was not until the aftermath of the endPermian mass extinction that bivalves numerically dominated the majority of nearshore and shelf environments globally (Fraiser and Bottjer, 2007b) (Fig. 4C). Perhaps the ability of bivalves to become the most abundant skeletonized invertebrate in benthic marine environments was due to the large extinction of rhynchonelliform brachiopods during the endPermian mass extinction, their preferential occupation of nearshore habitats, and physiological characteristics that enabled them to thrive during periods of oceanic and atmospheric stress during the Permian-Triassic transition.

Figure 4. Ecological dominants in post-Cambrian shell beds. (A, B) Ecological dominants in Ordovician to Permian and in post-Lower Triassic shell beds; from Kidwell (1991) and Fraiser and Bottjer (2007b). (C) Ecological dominants in Lower Triassic shell beds; data from Fraiser and Bottjer (2007b). Rhynchonelliform brachiopods numerically dominate Ordovician-Permian shell beds; bivalves numerically dominate Lower Triassic and post-Lower Triassic shell beds. N-total number of shell beds included in each analysis. No data for Lower Triassic shell beds were listed in Kidwell (1991). Data are from nearshore, inner shelf, and middle shelf environments.
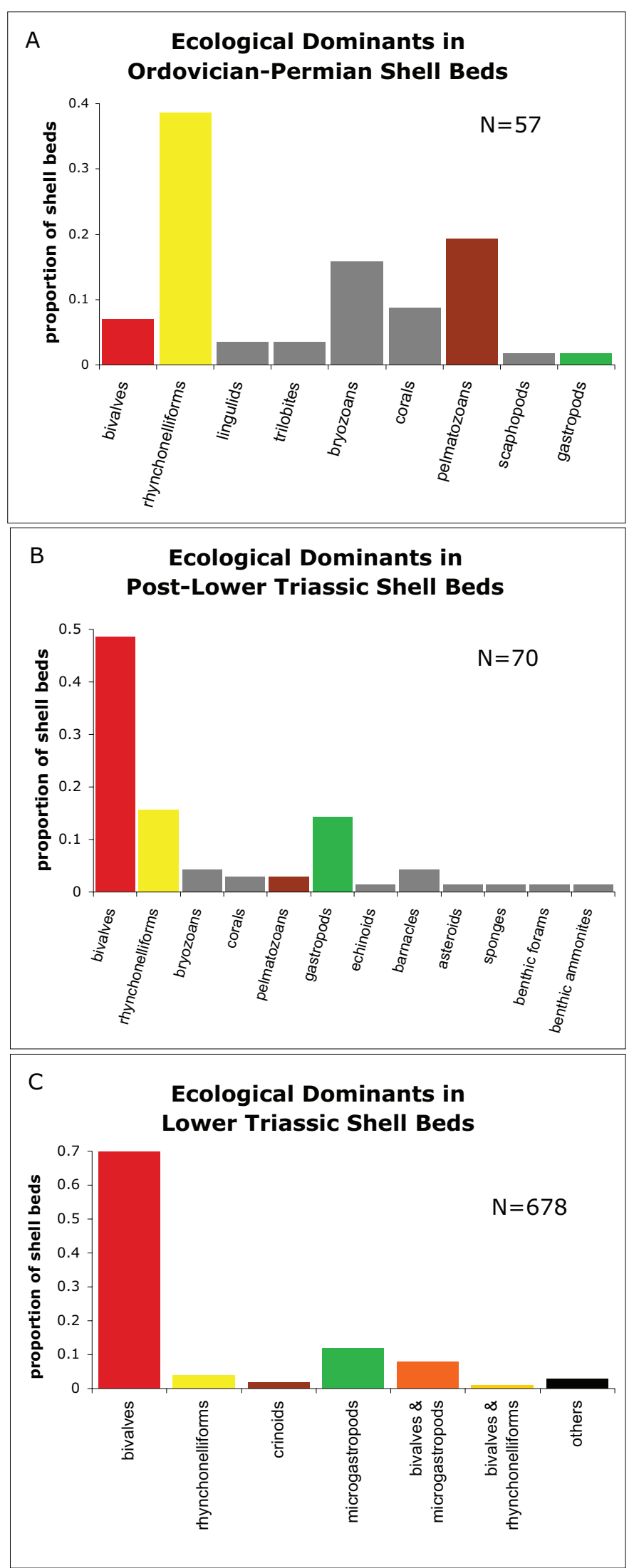
The devastation of the end-Permian mass extinction is also reflected in the onshore-offshore distribution of bryozoans during the Early Triassic, with most environments containing no bryozoans and only one to two genera in others (Powers and Bottjer, 2007) (Fig. 2A). Bryozoan assemblage generic diversity remained low across all marine settings until the Late Triassic, when they recolonized most marine environments (Fig. 2A). The paleobiogeographic range of bryozoans in the Early Triassic mirrors their sporadic environmental distribution, with bryozoan localities restricted to high-latitude settings along northwest Pangea in eastern Panthalassa (Fig. 2B), and contrasts sharply with their Permian cosmopolitan distribution and widespread environmental range, particularly within the Tethyan Sea (Powers and Bottjer, 2009). This suggests that the Boreal realm may have acted as a geographic refugium during the Early Triassic (Powers and Pachut, 2008) (Fig. 2B). The Middle and Late Triassic environmental recovery of bryozoans (Fig. 2A) is also reflected by a much broader geographic distribution than in the Early Triassic (Powers and Pachut, 2008).

These new faunal analyses show that some combination of the euxinic marine conditions that first appeared at the MiddleLate Permian boundary with new $\mathrm{CO}_{2}$ stress from Siberian volcanism continued through the Early Triassic (Isozaki, 1997; Payne and Kump, 2007). These environmental conditions adversely affected rhynchonelliform brachiopods and bryozoans but did not adversely affect a select group of benthic molluscs, which proliferated wildly during this time.

\section{DISCUSSION}

These results are consistent with a protracted oceanographic crisis during the Late Permian and Early Triassic. Unlike the mass extinction at the end of the Cretaceous, where taxonomic selectivity studies of brachiopods and bivalves indicate a crash in primary productivity associated with bolide impact (e.g., Rhodes and Thayer, 1991; Knoll et al., 2007), this Late PermianEarly Triassic crisis was likely caused by some combination of euxinia and/or high $\mathrm{CO}_{2}$ in the oceans. Questions about the precise kill mechanisms and physiological reasons for survivorship and opportunism can now be addressed by revisiting pioneering experimental approaches (e.g., Thayer, 1985), taking advantage of research programs that have been initiated to understand the modern crisis of greenhouse gas-linked environmental change (e.g., Hoegh-Guldberg et al., 2007; Knoll et al., 2007).

For example, exposure of modern scleractinian corals to elevated $\mathrm{CO}_{2}$ in microcosms resulted in skeleton dissolution and survival of the corals as soft polyps (Fine and Tchernov, 2007). As previously discussed, increased $\mathrm{CO}_{2}$ concentrations in seawater, with corresponding ocean acidification, are also conditions that occurred during the end-Permian mass extinction and the Early Triassic (Fraiser and Bottjer, 2007a). One of the most pronounced biotic changes during the end-Permian mass extinction was the disappearance of Paleozoic tabulate and rugose corals and coral reefs from the geological record and the emergence of scleractinian corals and reefs after the recovery interval in the Middle Triassic (e.g., Stanley and Fautin, 2001; Stanley, 2003, 2007). The microcosm experiments confirm that rather than becoming extinct, corals may have existed as soft-bodied, anemone-like forms through the Early
Triassic, only reappearing in the fossil record after ocean acidification subsided in the Middle Triassic so that they could once again form mineralized skeletons (Stanley, 2007).

These remarkable results with microcosm experiments demonstrate that future work should focus on studies of other modern organisms similar to those that died, as well as those that thrived, where levels of $\mathrm{O}_{2}, \mathrm{CO}_{2}$, and $\mathrm{H}_{2} \mathrm{~S}$ can be experimentally manipulated. For example, the shallow infaunal burrower Unionites is the most abundant of the dominant Early Triassic bivalves (Fraiser and Bottjer, 2007b). At other times, members of this extinct genus inhabited stressed environments (e.g., Posenato, 2008), and if a suitable stand-in for Early Triassic Unionites, with similar skeletal and physiological properties, could be found in the modern fauna, it might be possible to determine whether its resilience in the face of reduced $\mathrm{O}_{2}$ or increased $\mathrm{CO}_{2}$ or $\mathrm{H}_{2} \mathrm{~S}$ concentrations would have allowed it to dominate shallow benthic environments. Continued use of such innovative new approaches places even more detailed understanding of the nature of this greatest Phanerozoic biotic crisis within reach.

\section{ACKNOWLEDGMENTS}

F.A. Corsetti, P. Marenco, S.B. Pruss, N.M. Bonuso, and A.G. Fischer are thanked for discussion during the development of this research. P.B. Wignall, P.M. Sheehan, L.R. Kump, and D.E. Fastovsky provided valuable comments on an earlier version of the manuscript. This is Paleobiology Database publication no. 78 .

\section{REFERENCES CITED}

Atudorei, N.V., 1999, Constraints on the Upper Permian to Upper Triassic marine carbon isotope curve: case studies from the Tethys [Ph.D. thesis]: Lausanne, University of Lausanne, 160 p.

Becker, L., Poreda, R.J., Hunt, A.G., Bunch, T.E., and Rampino, M.R., 2001, Impact event at the Permian-Triassic boundary: Evidence from extraterrestrial noble gases in fullerenes: Science, v. 291, p. 1530-1533, doi: 10.1126/ science. 1057243.

Benton, M.J., 1995, Diversification and extinction in the history of life: Science, v. 268, p. 52-58, doi: 10.1126/science.7701342.

Bottjer, D.J., and Jablonski, D., 1988, Paleoenvironmental patterns in the evolution of post-Paleozoic benthic marine invertebrates: Palaios, v. 3, p. 540-560, doi: $10.2307 / 3514444$.

Clapham, M.E., and Bottjer, D.J., 2007a, Permian marine paleoecology and its implications for large-scale decoupling of brachiopod and bivalve abundance and diversity during the Lopingian (Late Permian): Palaeogeography, Palaeoclimatology, Palaeoecology, v. 249, p. 283-301, doi: 10.1016/j.palaeo.2007.02.003.

Clapham, M.E., and Bottjer, D.J., 2007b, Prolonged Permian-Triassic ecological crisis recorded by molluscan dominance in Late Permian offshore assemblages: Proceedings of the National Academy of Sciences of the United States of America, v. 104, p. 12,971-12,975, doi: 10.1073/pnas.0705280104.

Clapham, M.E., Bottjer, D.J., Powers, C.M., Bonuso, N., Fraiser, M.L., Marenco, P.J., Dornbos, S.Q., and Pruss, S.B., 2006, Assessing the ecological dominance of Phanerozoic marine invertebrates: Palaios, v. 21, p. 431-441, doi: 10.2110/ palo.2005.P05-017R.

Corsetti, F.A., Baud, A., Marenco, P.J., and Richoz, S., 2005, Summary of Early Triassic carbon isotope records: Comptes Rendus Palevol, v. 4, p. 473-486, doi: 10.1016/j.crpv.2005.06.004.

Erwin, D.H., 2006, Extinction: How Life on Earth Nearly Ended 250 Million Years Ago: Princeton, New Jersey, Princeton University Press, 296 p.

Erwin, D.H., and Pan, H., 1996, Recoveries and radiations: gastropods after the Permo-Triassic mass extinction, in Hart, M.B., ed., Biotic Recovery from Mass Extinction Events: London, Geological Society Special Publication 102, p. 223-229.

Fine, M., and Tchernov, D., 2007, Scleractinian coral species survive and recover from decalcification: Science, v. 315, p. 1811, doi: 10.1126/science.1137094.

Fraiser, M.L., and Bottjer, D.J., 2004, The non-actualistic Early Triassic gastropod fauna: A case study of the Lower Triassic Sinbad Limestone Member: Palaios, v. 19, p. 259-275, doi: 10.1669/0883-1351(2004)019<0259:TNETGF> 2.0.CO;2.

Fraiser, M.L., and Bottjer, D.J., 2007a, Elevated atmospheric $\mathrm{CO}_{2}$ and the delayed biotic recovery from the end-Permian mass extinction: Palaeogeography, Palaeoclimatology, Palaeoecology, v. 252, p. 164-175, doi: 10.1016/j.palaeo. 2006.11.041. 
Fraiser, M.L., and Bottjer, D.J., 2007b, When bivalves took over the world: Paleobiology, v. 33, p. 397-413, doi: 10.1666/05072.1.

Fraiser, M.L., Twitchett, R.J., and Bottjer, D.J., 2005, Unique microgastropod biofacies in the Early Triassic: Indicator of long-term biotic stress and the pattern of biotic recovery after the end-Permian mass extinction: Comptes Rendus Palevol, v. 4, p. 475-484.

Gould, S.J., and Calloway, C.B., 1980, Clams and brachiopods-ships that pass in the night: Paleobiology, v. 6, p. 383-396.

Grice, K., Cao, C., Love, G.D., Böttcher, M.E., Twitchett, R.J., Grosjean, E., Summons, R.E., Turgeon, S.C., Dunning, W., and Jin, Y., 2005, Photic zone euxinia during the Permian-Triassic superanoxic event: Science, v. 307, p. 706-709, doi: 10.1126/science. 1104323 .

Hallam, A., 1991, Why was there a delayed radiation after the end-Palaeozoic extinctions?: Historical Biology, v. 5, p. 257-262.

Hallam, A., and Wignall, P.B., 1997, Mass Extinctions and their Aftermath: New York, Oxford University Press, $320 \mathrm{p}$.

Hoegh-Guldberg, O., Mumby, P.J., Hooten, A.J., Steneck, R.S., Greenfield, P., Gomez E., Harvell, C.D., Sale, P.F., Edwards, A.J., Caldeira, K., Knowlton, N., Eakin, C.M., Iglesias-Prieto, R., Muthiga, N., Bradbury, R.H., Dubi, A., and Hatziolos, M.E., 2007, Coral reefs under rapid climate change and ocean acidification: Science, v. 318, p. 1737-1742, doi: 10.1126/science 1152509

Huey, R.B., and Ward, P.D., 2005, Hypoxia, global warming, and terrestrial Late Permian extinctions: Science, v. 308, p. 398-401, doi: 10.1126/science. 1108019.

Isozaki, Y., 1997, Permo-Triassic boundary superanoxia and stratified superocean: Records from lost deep sea: Science, v. 276, p. 235-238, doi: 10.1126/ science.276.5310.235

Jablonski, D., Sepkoski, J.J., Jr., Bottjer, D.J., and Sheehan, P.M., 1983, Onshoreoffshore patterns in the evolution of Phanerozoic shelf communities: Science, v. 222, p. 1123-1125, doi: 10.1126/science.222.4628.1123.

Kamo, S.L., Czamanske, G.K., Amelin, Y., Fedorenko, V.A., Davis, D.W., and Trofimov, V.R., 2003, Rapid eruption of Siberian flood-volcanic rocks and evidence for coincidence with the Permian-Triassic boundary and mass extinction at 251 Ma: Earth and Planetary Science Letters, v. 214, p. 75-91, doi: 10.1016/S0012 $821 \times(03) 00347-9$

Kidwell, S.M., 1991, The stratigraphy of shell concentrations, in Allison, P.A., and Briggs, D.E.G., eds., Taphonomy: Releasing the data locked in the fossil record: New York, Plenum, p. 211-290.

Kidwell, S.M., 2001, Preservation of species abundance in marine death assemblages: Science, v. 294, p. 1091-1094, doi: 10.1126/science.1064539.

Kidwell, S.M., 2002, Time-averaged molluscan death assemblages: Palimpsests of richness, snapshots of abundance: Geology, v. 30, p. 803-806, doi: 10.1130/ 0091-7613(2002)030<0803:TAMDAP>2.0.CO;2.

Knoll, A.H., Bambach, R.K., Canfield, D.E., and Grotzinger, J.P., 1996, Comparative earth history and Late Permian mass extinction: Science, v. 273, p. 452-457, doi: 10.1126/science.273.5274.452.

Knoll, A.H., Bambach, R.K., Payne, J.L., Pruss, S., and Fischer, W.W., 2007, Paleophysiology and end-Permian mass extinction: Earth and Planetary Science Letters, v. 256, p. 295-313, doi: 10.1016/j.epsl.2007.02.018.

Krull, E.S., and Retallack, G.J., 2000, $\delta^{13} \mathrm{C}$ depth profiles from paleosols across the Permian-Triassic boundary: Evidence for methane release: Geological Society of America Bulletin, v. 112, p. 1459-1472.

Kump, L.R., Pavlov, A., and Arthur, M.A., 2005, Massive release of hydrogen sulfide to the surface ocean and atmosphere during intervals of oceanic anoxia: Geology, v. 33, p. 397-400, doi: 10.1130/G21295.1.

Lehrmann, D.J., Ramezani, J., Bowring, S.A., Martin, M.W., Montgomery, P., Enos, P. Payne, J.L., Orchard, M.J., Wang, H., and Wei, J., 2006, Timing of recovery from the end-Permian extinction: geochronologic and biostratigraphic constraints from south China: Geology, v. 34, p. 1053-1056, doi: 10.1130/G22827A.1.

Li, X., and Droser, M.L., 1999, Lower and Middle Ordovician shell beds from the Basin and Range Province of the Western United States (California, Nevada, and Utah): Palaios, v. 14, p. 215-233, doi: 10.2307/3515435.

Miller, A.I. 1988, Spatio-temporal transitions in Paleozoic Bivalvia: An analysis of North American fossil assemblages: Historical Biology, v. 1, p. 251-273.

Nielsen, J.K., and Shen, Y., 2004, Evidence for sulfidic deep water during the Late Permian in the East Greenland Basin: Geology, v. 32, p. 1037-1040, doi: 10.1130/G20987.1.

Payne, J.L., and Kump, L.R., 2007, Evidence for recurrent Early Triassic massive volcanism from quantitative interpretation of carbon isotope fluctuations: Earth and
Planetary Science Letters, v. 256, p. 264-277, doi: 10.1016/j.epsl. 2007.01.034.

Payne, J.L., Lehrmann, D.J., Wei, J., Orchard, M.J., Schrag, D.P., and Knoll, A.H., 2004, Large perturbations of the carbon cycle from the End-Permian extinction Science, v. 305, p. 506-509, doi: 10.1126/science.1097023.

Posenato, R., 2008, Patterns of bivalve biodiversity from Early to Middle Triassic in the Southern Alps (Italy): Regional vs. global events: Palaeogeography, Palaeoclimatology, Palaeoecology, v. 261, p. 145-159, doi: 10.1016/j.palaeo. 2008.01.006.

Power, M.E., Tilman, D., Estes, J.A., Menge, B.A., Bond, W.J., Mills, L.S., Daily, G., Castilla, J.C., Lubchenco, J., and Paine, R.T., 1996, Challenges in the quest for keystones: Bioscience, v. 46, p. 609-620, doi: 10.2307/1312990.

Powers, C.M. and Bottjer, D.J. 2007, Bryozoan paleoecology indicates mid-Phanerozoic extinctions were the product of long-term environmental stress: Geology, v. 35, p. 995-998, doi: 10.1130/G23858A.1

Powers, C.M., and Bottjer, D.J., 2009, The effects of mid-Phanerozoic environmental stress on bryozoan diversity, paleoecology, and paleogeography: Global and Planetary Change, in press.

Powers, C.M., and Pachut, J.F., 2008, Diversity and distribution of Triassic bryozoans in the aftermath of the end-Permian mass extinction: Journal of Paleontology, 82, p. 362-371, doi: 10.1666/06-131.1.

Pruss, S.B., Fraiser, M., and Bottjer, D.J., 2004, The proliferation of Early Triassic wrinkle structures: implications for environmental stress following the end-Permian mass extinction: Geology, v. 32, p. 461-464, doi: 10.1130/G20354.1.

Pruss, S.B., Bottjer, D.J., Corsetti, F.A., and Baud, A., 2006, A global marine sedimentary response to the end-Permian mass extinction: examples from southern Turkey and the western United States: Earth-Science Reviews, v. 78 p. 193-206, doi: 10.1016/j.earscirev.2006.05.002.

Raup, D.M., and Sepkoski, J.J., 1982, Mass extinctions in the marine fossil record: Science, v. 215, p. 1501-1503, doi: 10.1126/science.215.4539.1501

Renne, P.R., Zichao, Z., Richards, M.A., Black, M.T., and Basu, A.R., 1995, Synchrony and causal relations between Permian-Triassic boundary crises and Siberian flood volcanism: Science, v. 269, p. 1413-1416, doi: 10.1126/science. 269.5229.1413

Rhodes, M.C., and Thayer, C.W., 1991, Mass extinctions: ecological selectivity and primary production: Geology, v. 19, p. 877-880, doi: 10.1130/0091-7613(1991) $019<0877$ :MEESAP $>2.3$ CO 2

Ryskin, G., 2003, Methane-driven oceanic eruptions and mass extinctions: Geology, v. 31, p. 741-744, doi: 10.1130/G19518.1.

Schubert, J.K and Bottjer, DJ 1992, Early Triassic stromatolites as post-mass extinction disaster forms: Geology, v. 20, p. 883-886, doi: 10.1130/0091-7613(1992) $020<0883$ :ETSAPM $>2.3$.CO;2

Sepkoski, J.J., 1981, A factor analytic description of the Phanerozoic marine fossil record: Paleobiology, v. 7, p. 36-53.

Sepkoski, J.J., and Miller, A.I., 1985, Evolutionary faunas and the distribution of Paleozoic marine communities in space and time, in Valentine, J.W., ed., Phanerozoic Diversity Patterns: Profiles in Macroevolution: Princeton, New Jersey, Princeton University Press, p. 153-190.

Stanley, G.D., Jr., 2003, The evolution of modern corals and their early history: EarthScience Reviews, v. 60, p. 195-225, doi: 10.1016/S0012-8252(02)00104-6.

Stanley, G.D., Jr., 2007, Ocean acidification and scleractinian corals: Science, v. 317 1032, doi: $10.1126 /$ science.317.5841.1032c

Stanley, G.D., Jr., and Fautin, D.G., 2001, The origins of modern corals: Science v. 291, p. 1913-1914, doi: 10.1126/science.1056632.

Stanley, S.M., and Yang, X., 1994, A double mass extinction at the end of the Paleozoic era: Science, v. 266, p. 1340-1344, doi: 10.1126/science.266.5189.1340.

Thayer, C.W., 1985, Brachiopods versus mussels: competition, predation, and palatability: Science, v. 228, p. 1527-1528, doi: 10.1126/science.228.4707.1527.

The Paleobiology Database, 2008: http://paleodb.org/cgi-bin/bridge.pl (last accessed 24 June 2008).

Wignall, P.B., and Twitchett, R.J., 1996, Oceanic anoxia and the End Permian mass extinction: Science, v. 272, p. 1155-1158, doi: 10.1126/science. 272.5265 .1155

Woods, A.D., Bottjer, D.J., Mutti, M., and Morrison, J., 1999, Lower Triassic large seafloor carbonate cements: Their origin and a mechanism for the prolonged biotic recovery from the end-Permian mass extinction: Geology, v. 27, p. 645-648, doi: 10.1130/0091-7613(1999)027<0645:LTLSFC>2.3.CO;2.

Manuscript received 17 January 2008; accepted 27 May 2008.
GSA ANNOUNCES NEW JOURNAL FOR 2009

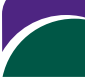

THE GEOLOGICAL SOCIETY OF AMERICA ${ }^{\circledR}$ Lithosphere

The Geological Society of America is pleased to announce Lithosphere, a monthly journal to be launched in early 2009. For more information, go to www.gsajournals.org.

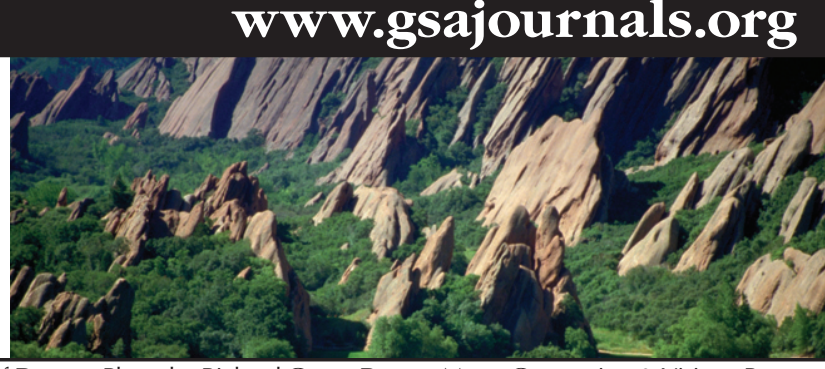

